\title{
鼻腔，頸部リンパ節，肺に多発した結核例
}

\author{
木下 晶子・湯本 英二*
}

\section{A Case Report of Tuberculosis with Multiple Affections as in the Nose, the Cervical Lymphnodes and the Lung}

\author{
Masako Kinoshita \\ (Nishinihon Hospital) \\ Eiji Yumoto \\ (Kumamoto University)
}

We report a patient with tuberculosis in the nasal cavity, cervical lymph nodes and the lung. The patient's main complaint was rhinorrhea when she visited our clinic. The patient was a 67 year-old female who suffered from hypersecretion of the nose for approximately 5 years. The findings showed a nasal septum perforation and granuloma development on the bilateral inferior nasal turbinate. The perforation margin of the septum tended to bleed easily. The pathological finding of a biopsied specimen from the granuloma indicated some difficulties for differentiating between Wegener's granulomatosis and tuberculosis. Since the patient also had cervical lymph node swelling, we performed a surgical biopsy of the neck. The final diagnosis was tuberculosis.

During the diagnostic procedure, millions of lesions in the lung were noted, which were found by a chest X-ray examination.

The patient was treated with antituberculosis drugs such as streptomycin, isoniazid and rifampicin. The affections in the nose, cervical lymph nodes and the lung were brought into complete remission.

Nasal tuberculosis is a rare and important disease, which has to be differentiated from other inflammatory diseases as well as malignant tumors of the nose.

Key words : tuberculosis, nasal cavity, Wegener's granulomatosis

はじめに

日本に拈ける結核は，年々減少傾向にあったが近年再 び増加の傾向がみられるようになり，平成 9 年には 42715 人が新登録され38年ぶりに増加した1). また，院 内集団感染などが相次ぎ社会的問題となっている. その ため平成11年 7 月 26 日に厚生省より結核緊急事態宣言が なされた. 今回, ウェゲナー肉芽腫と鑑別を要した鼻腔 結核を経験したので，若干の文献的考察を含め報告する.

\section{症例}

症例 : 67歳, 女性.

主訴 : 鼻漏.

現病歴 : 平成元年頃より鼻漏出現するも放置していた. 平成 10 年 5 月上旬, 鼻漏増悪し両側頸部腫瘤が出現して きたため，平成10年 5 月 20 日当科初診となった。

既往歴: 平成 5 年 脳梗塞.

家族歴 : 特記すべきことなし. 
初診時所見：鼻中隔に穿孔を認め, 穿孔縁特よび両側 下鼻甲介前端に肉芽の增生を認めた。両側上内深頸領域 飞小指頭大リンパ節腫脹を多数認め, 弾性硬可動性は不 良で周囲との癒着を認めた。厈痛はなく，境界は比較的 明膫であった。その他，耳，咽喉頭には異常は認められ なかった，初診時，精查目的で入院となり，鼻腔肉芽性 病变より 3 力所から生検索施行した。

CT 所見：鼻中隔穿孔があり，その周辺の軟部陰影を 認めた。上罘洞，篩骨洞，蝶形骨洞には軟部陰影は認め なかった(図 1，2）。両側上内深頸領域に内部が低吸収 で周囲が造影されるリンパ節を多数認めた(図 3 )。また，

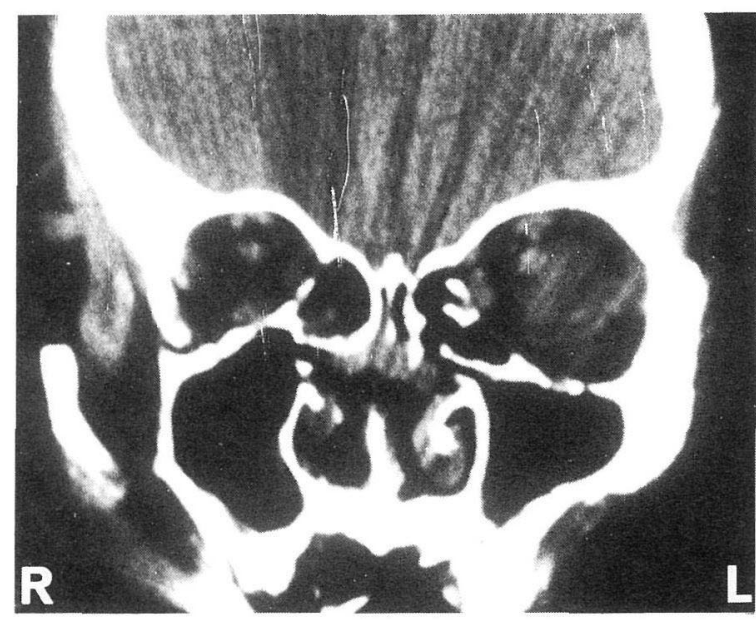

図 1

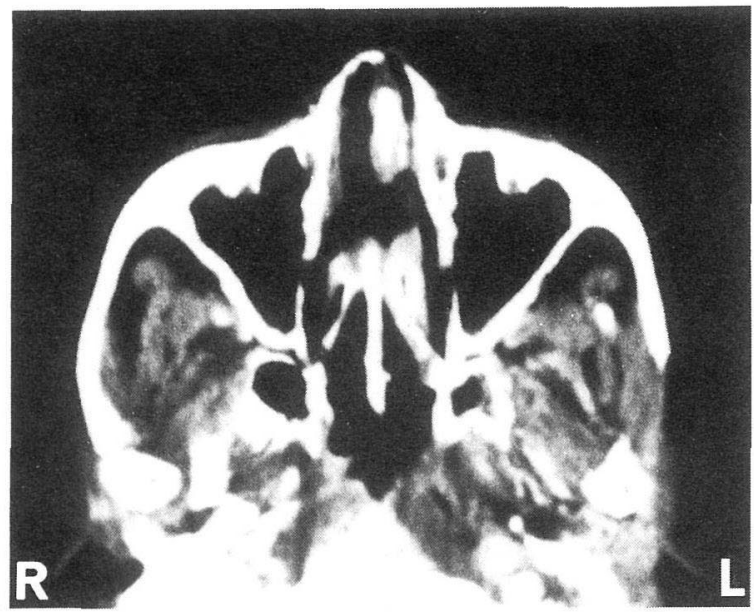

図 2

図 1,2 副鼻腔単純 CT

鼻中隔に穿孔があり，穿孔縁に軽度の軟部陰影を認 める。上顎洞には陰影は認めない。

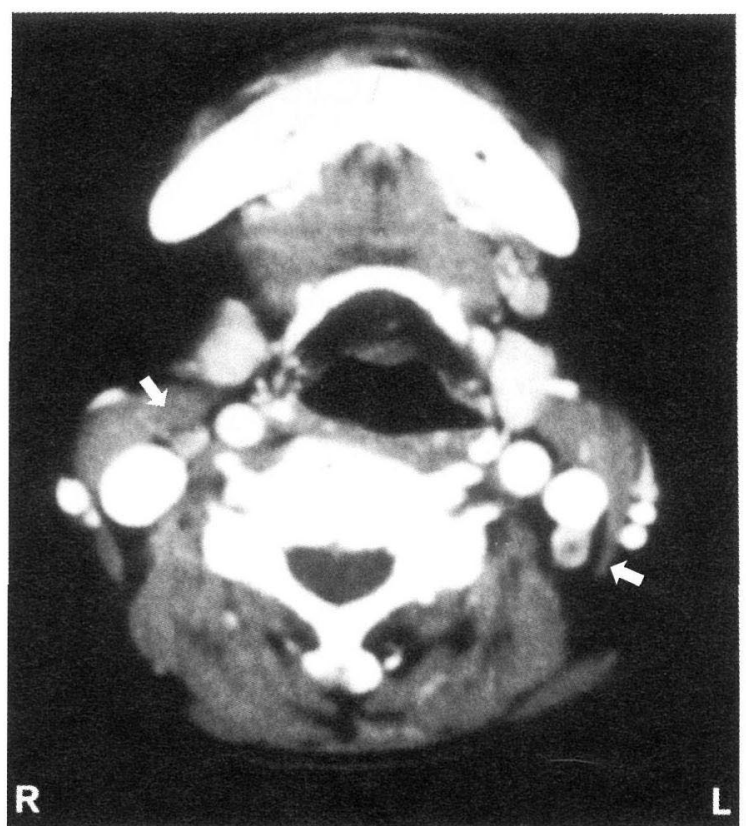

図 3 両側上内深頸領域にリンパ節( ()を認める.

胸部単純 CT では異常陰影は指摘できなかった。

検查所見: 白血球数, へモグロビン值が軽度低下を示 し， CRP は軽度上昇, 血沈は高度光進していた。ッベ ルクリン反応中等度陽性であり, c-ANCA は陰性であっ た。鼻漏扣よび喀痰に扣いて結核菌塗沫検鏡検査, 培養 検査, 結核菌 PCR 法による検查を行い, いずれる陰性 であった(表1)。また, 病理組織検査の結果, 多数のり ンパ球, 好中球, 形質細胞の浸潤があり, 血管周囲に>ィ

表 1 検查所見

体温 $36.6^{\circ} \mathrm{C}$ 血圧 $120 / 80 \mathrm{mmHg}$ 心拍数 72 回/分 (整) 呼吸数16回/分

血液検查

白血球1980 赤血球304万 $\mathrm{Hb} 9.3 \mathrm{~g} / \mathrm{dl} \quad \mathrm{Ht} 32.9 \%$ 血小板 21.7 万

血清総タンパク $7.5 \mathrm{~g} / \mathrm{dl}$ 総ビリルビン $0.2 \mathrm{mg} / \mathrm{dl}$ GOT 14 IU/L GPT 6 IU/L ALP 165 IU/L

$\mathrm{LDH} 268 \mathrm{IU} / \mathrm{L}$ 血糖值 $93 \mathrm{mg} / \mathrm{dl} \quad \mathrm{Cr} 0.9 \mathrm{mg} / \mathrm{dl}$ $\mathrm{K} 4.1 \mathrm{mEq} / 1 \quad \mathrm{Cl} 102 \mathrm{mEq} / 1$

CRP 2.6 IU/L 血沈 $106 \mathrm{~mm}$ ( 1 時間值)

$143 \mathrm{~mm}$ ( 2 時間値)

c-ANCA 陰性

ツベルクリン反応 中等度陽性 $(25 \times 21 \mathrm{~mm}$, 硬結めり $)$ 


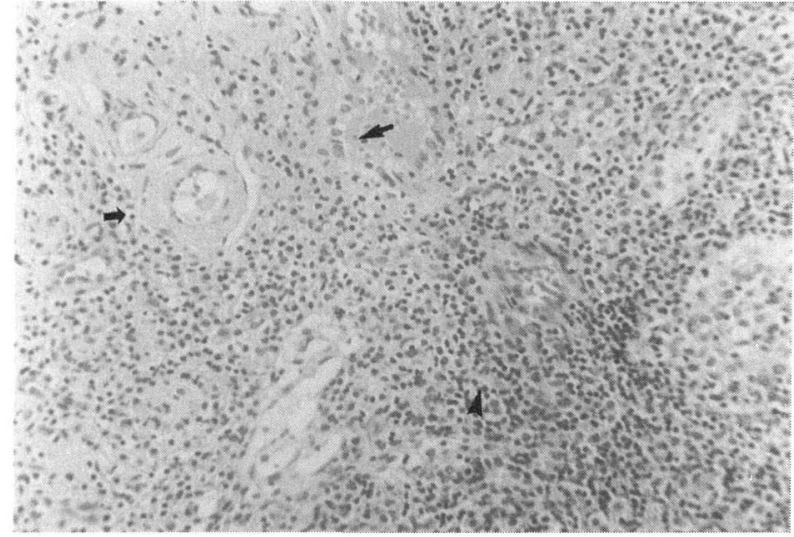

図 4 リンハ球 (>), 類上皮細胞 ( $($ ), 好中球, 形質細胞の浸 潤を認め, 血管周囲にフィブリノイド変性 ( 妾伴って いる $($ HE 染色 $\times 200)$.

ブリノイド変性を伴い, 類上皮細胞の増加を認め(図 4), 結核とウェゲナー肉芽腫の鑑別が問題となった。チール ニールセン染色では結核菌は証明されなかった。

経過 : 確定診断がつかないため頸部リンパ節の生検を 計画したが，患者の同意を得られず，平成10年 6 月 1 日 いったん退院となった。退院後, 両側頸部りンパ節腫脹 が增大したため 7 月 9 日再入院の上, 左頸部りンパ節生 検を施行した、リンパ節は周团との癒着があり硬く割面 は一部石灰化を伴っていた。 7 月 14 日に $38^{\circ} \mathrm{C}$ の発熱が 出現し, 胸部単純 $\mathrm{CT}$ 上, 両側下肺野を中心飞小結節性 病変が多数出現した。

7 月17日の病理組織検查の結果, 乾酪性壞死性肉芽腫

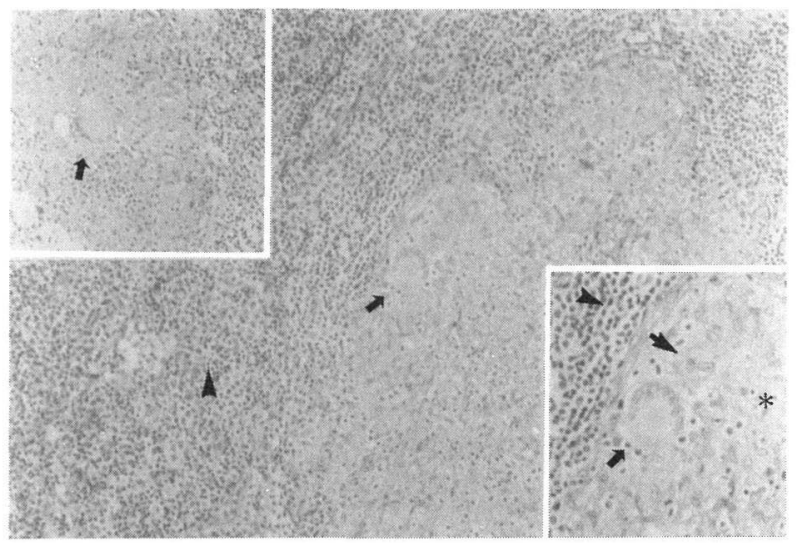

図 5 乾酷性壊死像 $(*)$ 周图に, ラングハンス巨細胞 $(\Rightarrow)$, 類 上皮細胞 $(\rightarrow)$ 扮よび，多数のリンパ球 ( つ)の浸潤を認め る $(\mathrm{HE}$ 染色 $\times 200$ : 中央, $\times 400$ : 左上・右下 $)$.
を認め(図 5 ) 結核と診断し，ただらに硫酸ストレプトマ イシン，イソニアジド，リファンピシンの 3 剤併用療法 を開始した。をた，今回も喀痰からの塗沫検鏡検査は陰 性であったが，肺病変も結核の可能性が高く 7 月 20 日結 核療養所への転院となった。 その後も 3 剤併用療法続行 され, 肺拉よび鼻腔の病変の消失を認め約 2 力月後に退 院となった.

\section{考察}

結核は, 過去の疾病ではなく最近では再興感染症の一 つに挙げられている2). 現在では結核の集団感染が相次 いで括り, 病院内集団感染も問題となっている. 医療関 係者内での結核に対する認識不足により結核の診断の遅 れが結核の蔓延を助長していると考光られている32. 今 回経験した症例に関し，患者の希望により一時退院した ため診断が遅れたことが反省点である。幸いにも病院内， 家族内での結核発病者はいなかった。ウェゲナー肉芽腫 と結核では治療法が，前者はステロイドと免疫抑制剤が 主力となり，結核であるならば増悪する可能性も高く， 診断に慎重にならざるを得なかった，鼻汁塗洙検鏡検査， PCR 法は 3 回とも陰性でありまたチールニールセン 染色でも結核菌は証明できなかった。唯一，ッベルクリ ン反応が中等度陽性で結核を疑わせる所見であったが確 定までには至らなかった。病变部位への効果をみるため, 診断的治療として抗結核剤の投与を試みるのも一つの方 法と思われた。

副鼻腔に病変がなく鼻腔に限局している結核はめずら しく,われわれが渉孜し得た限りでは本症例も含め 21 症 例であった4)。鼻腔でも，鼻中隔，下甲介の順にみら れ5)，本症例でも鼻中隔穿孔縁拉よび両側下甲介に肉芽 性病変を認めた。な和，鼻中隔穿孔をたす疾患は，田 沼ら ${ }^{6)}$ は, 特異的感染症では結核, 癩, 梅毒があり膠原 病，ウェゲナー肉芽腫，白血病や 6 価ク口ムなど職業性 のもの，鼻腔の手術によるものなどを鑑別疾患として挙 げている，鼻腔結核は女性に多く，青，高年層に多く認 められる77。また，鼻腔結核症の病型としては大きく潰 瘍型と増殖型に分類されている。潰瘍型は肺結核に続発 することが多く痂皮を伴った潰瘍形成が主で，病変部位 に結核菌を証明できることが多く，逆に増殖型では，肉 芽形成を主とし，病巣部位の結核菌も少なく培着を行っ ても結核菌を証明できないことが多いとされる8)。次に， 鼻副鼻腔結核症の感染経路については原発性之続発性が 
あり，原発性では機械的損傷を受けた部位に病変が認め られることが多く, 続発性では結核病巣から血行性ある いはリンパ行性に感染するもの, 隣接蔵器からの連続伝 播によるものが考兄られている9). 本症例では副鼻腔に 陰影なく鼻症状が先行していることにより, 鼻腔が原発 でリンパ行性に頸部リンパ節へ, 肺は粟粒結核の状態で あり血行性に肺へ感染したものと考えた。

診断については, 結核鏡検検查, 培養検査, ツベルク リン反応, 病理組織検査, PCR 法などがある. 検鏡検 查で 1 視野に 1 個結核菌がみられると, 感染の危険が高 いとされるガフキー 3 号である。これは喀痰 $1 \mathrm{ml}$ あた り100万個の菌量であり, 検鏡検査は迅速ではあるが鼻 腔結核に打いて菌量が少なく陰性の可能性が高い。一方 培養法は時間が $4 \sim 8$ 週間かかるが確実な検查法であ る9). また, PCR 法は感度, 特異度ともに優れているが 実用面では培養法を越えるものではなく10), 抗結核㓮の 感受性検査ができないので注意が必要である11).

治療については抗結核剤の投与が基本であるが頸部結 核性リンパ節炎などで膿瘍を形成したものでは手術が必 要である. 抗結核剤については, 鼻腔結核や頸部結核性 リンパ節炎に対する特有の化学療法はないが, 肺結核の 化学療法 ${ }^{12)}$ に沿って治療薬, 治療期間を選択したほう が良いようである.最近ではストレプトマイシン, イソ ニアジド，リファンピシンに，再び脚光を浴びているピ ラジナミドを組み入れた強力な化学療法も考兄られてい る. また，一方で抗結核阂耐性の結核菌の出現も問題と なってきている，その対策としては，正確な薬剤感受性 試験が必要で, 外科的治療も考慮し, さらに自然治癒力 にも期待するため長期入院が必要となる．そのため院内 感染対策にも気を配らなければならない13).

結核は過去の病気ではなく, “再興感染症の雄”とさ えいわれている1)。一般人の結核症に対する認識不足を 啓蒙により是正し，医療側の診断の遅れを防ぐため，結 核症は耳鼻咽喉科領域に括いても日常診察上, 常に念頭 に置かなければならない疾患の一つである.

\section{結語}

1.ウェゲナー肉芽腫と鑑別を要した鼻腔結核を報告 した，鼻腔肉芽性病変の鑑別の一つに結核が挙げられ
る.

2. 結核は過去の病気ではなく日頃の診療上，常に注 意すべき疾患である。

本論文の要旨は第61回耳鼻咽喉科臨床学会(1999年 6 月, 大 分)にて発表した.

稿を終觉るにあたり，この論文を御校閲いただいた九州アレ ルギー・免废センター石川 哮先生に深謝いたします。

\section{参考文献}

1）厚生省保険医療局結核感染症課監修：結核の統計 1998. 33 頁, 結核予防会, 東京, 1998.

2 ）和田 功 : Emrging Infectious Diseases の現状と対策. 臨床検查 $42: 503 \sim 511,1998$.

3 ) 青木正和 : 一般病院での結核菌陽性患者の実態. 日胸 57 : 689 695, 1998.

4 ）金子卓爾, 渡辺昭司, 中島博昭 : 原発鼻結核例. 耳鼻臨床 89 : 691 694, 1996.

5 ）田原哲也, 大上麻由里 : 原発鼻腔結核の 1 症例. 耳展 36 : 723 726, 1993.

6 ）田沼 文, 三島陽人, 加瀬康弘, 他 : 鼻中隔穿孔の臨床的 検討. 日耳鼻 $102: 878 \sim 882,1999$.

7 ）前野博昭, 雲井一夫, 小池 薰: 鼻・副鼻腔結核の 2 症例. 耳鼻臨床 $88: 1269 \sim 1277,1995$.

8 ）山内由紀, 大森英生, 関本邦彦: 鼻腔結核の 2 症例. 耳鼻 臨床 $87: 1659 \sim 1663,1994$.

9 ）倉島篤行：結核症の診断. 化療の領域 $14: 605 \sim 610,1998$.

10）阿部千代治：結核菌検索法の最近の進歩. 日胸 $57: 786 \sim$ 792, 1998.

11）加藤元一，木下貴裕 : 結核性リンパ節炎. 日臨 $56: 3122$ $\sim 3125,1998$.

12) Recomendations from the committee on treatment of international union against tuberculosis and lung disease; antituberculosis regimes of chemotherapy. Bul Int Tuberc $63: 60 \sim 64,1988$.

13）尾形英雄 : 多剂耐性結核の予防と対策. 化療の領域 14 : $639 \sim 645,1998$.

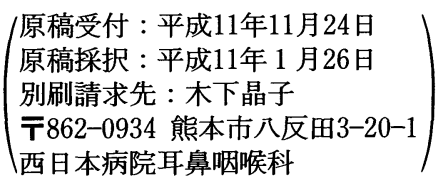

